Journal of

\section{Global History}

Published for London School of Economics and Political Science

\section{Chief Editor}

William Gervase Clarence-Smith, SOAS, London, UK

\section{Editors}

Barbara Watson Andaya, University of Hawaii, USA

Merry Wiesner-Hanks, University of Wisconsin-Milwaukee, USA

Journal of Global History addresses the main problems of global change over time, together with the diverse histories of globalization. It also examines countercurrents to globalization, including those that have structured other spatial units. The journal seeks to transcend the dichotomy between 'the West and the rest', straddle traditional regional boundaries, relate material to cultural and political history, and overcome thematic fragmentation in historiography. The journal also acts as a forum for interdisciplinary conversations across a wide variety of social and natural sciences.

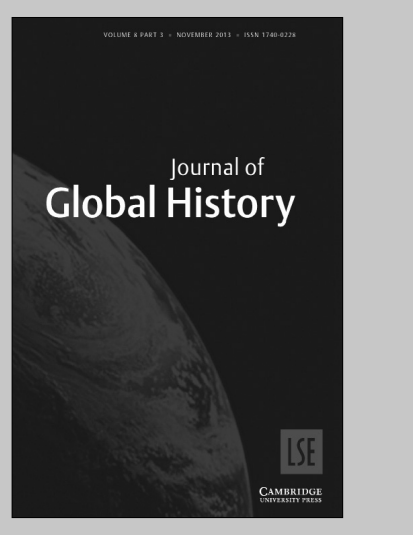

Journal of Global History is available online at: http://journals.cambridge.org/jgh

To subscribe contact Customer Services

\section{Americas:}

Phone +1 (845) 3537500

Fax +1 (845) 3534141

Email

subscriptions_newyork@cambridge.org

\section{Rest of world:}

Phone +44 (0)1223 326070

Fax +44 (0)1223 325150

Email journals@cambridge.org

\section{Free email alerts}

Keep up-to-date with new material - sign up at

journals.cambridge.org/register 


\section{CAMBRIDGE}

\section{JOURNALS}

\section{The \\ Historical \\ Journal}

\section{Editors}

Andrew Preston, University of Cambridge, UK

Phil Withington, University of Sheffield, UK

Founded in 1958, The Historical Journal publishes on all aspects of history since 1500, providing a forum for younger scholars making a distinguished debut as well as publishing the work of historians with an international reputation. The journal publishes original research in full-length articles and shorter communications and major surveys of the field in historiographical reviews and review articles. Contributions are aimed both at specialists and non-specialists.

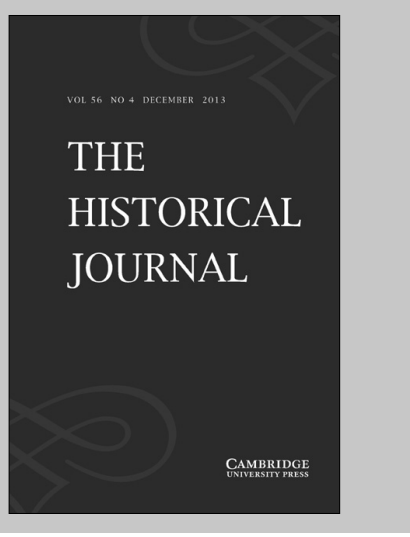

Historical Journal

is available online at: http://journals.cambridge.org/his

To subscribe contact Customer Services

\section{Americas:}

Phone +1 (845) 3537500

Fax +1 (845) 3534141

Email

subscriptions_newyork@cambridge.org

\section{Rest of world:}

Phone +44 (0)1223 326070

$\mathrm{Fax}+44(0) 1223325150$

Email journals@cambridge.org

\section{Free email alerts}

Keep up-to-date with new material - sign up at

journals.cambridge.org/register 
Royal Historical Society

\section{Publications}

Published on behalf of The Royal Historical Society

\section{RHS Literary Directors}

Ian W. Archer, University of Oxford, UK

Emma Griffin, Univeristy of East Anglia, UK

The Royal Historical Society has published the highest quality scholarship in history for over 150 years. A subscription includes a substantial annual volume of the Society's Transactions, which presents wide-ranging reports from the front lines of historical research by both senior and younger scholars, and two volumes from the Camden Fifth Series, which makes available to a wider audience valuable primary sources that have hitherto been available only in manuscript form.

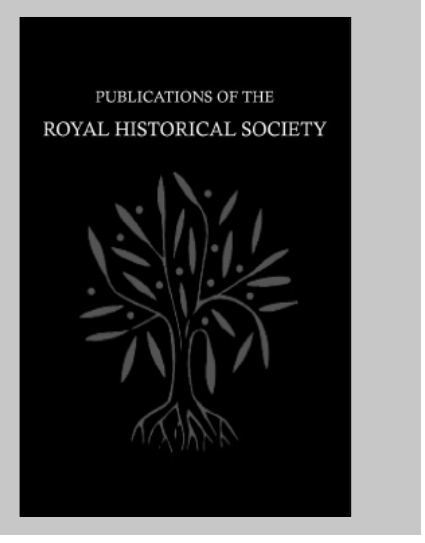

\section{Royal Historical Society} Publications

is available online at: http://journals.cambridge.org/rhs

To subscribe contact Customer Services

\section{Americas:}

Phone +1 (845) 3537500

Fax +1 (845) 3534141

Email

subscriptions_newyork@cambridge.org

\section{Rest of world:}

Phone +44 (0)1223 326070

Fax +44 (0)1223 325150

Email journals@cambridge.org

\section{Free email alerts}

Keep up-to-date with new material - sign up at

journals.cambridge.org/register 


\section{Instructions for contributors}

$\mathrm{MIH}$ serves as a focal point and forum for scholarship in intellectual history and its related fields, from the period of 1650 to the present. Though its primary focus is on Europe and the United States, it also devotes attention to global intellectual and cultural exchanges. In so doing, $M I H$ concerns itself primarily with apprehending the contextual origins and receptions of texts in order to recover their historical meanings. But we understand 'texts' in the broadest sense, so as to encompass multiple forms of intellectual and cultural expression. These include, but are not limited to, political thought, philosophy, religion, literature, both the social sciences and the natural sciences, music, architecture and the visual arts.

\section{SUBMISSIONS}

Articles submitted for consideration should be sent to Modern Intellectual History, Boston University, Department of History, 226 Bay State Road, Boston, MA 02215, usa. Email mih@bu.edu

Submission of a paper will be taken to imply that it is unpublished (even in a language other than English) and is not being considered for publication elsewhere. Upon acceptance of a paper, the author will be asked to assign copyright (on certain conditions) to Cambridge University Press.

Contributors are responsible for obtaining permission to reproduce any material in which they do not hold copyright for worldwide publication in all forms and media, including electronic publication, and for ensuring that the appropriate acknowledgements are included in their manuscript.

\section{MANUSCRIPT PREPARATION}

Contributors must follow the layout and stylistic conventions of $\mathrm{MIH}$. Detailed Instructions for contributors can be obtained from the Web at http://journals.cambridge.org/journal_ ModernIntellectualHistory.

The recommended length of articles is 10,000-12,000 words including footnotes. The recommended length of review essays is $\mathbf{5 , 0 0 0}$ words including footnotes.

Articles should normally be written in English. Spelling may follow either British or American convention but must be consistent.

Contributors should submit an electronic copy in Word as an email attachment.

\section{PROOFS}

Typographical or factual errors only may be changed at proof stage. The publisher reserves the right to charge authors for correction of non-typographical errors.

\section{OFFPRINTS}

No paper offprints are provided, but the corresponding author will be sent the pdf of the published article. Print offprints may be purchased at extra cost at proof stage.

Orders, which must be accompanied by payment, may be sent to a bookseller, subscription agent or direct to the publisher: Cambridge University Press, The Edinburgh Building, Shaftesbury Road, Cambridge CB2 2RU; or in the usa, Canada and Mexico: Cambridge University Press, Journals Fulfillment Department, 100 Brook Hill Drive, West Nyack, New York 10994-2133. Periodicals postage paid at New York, NY and at additional mailing offices.

\section{Copying}

This journal is registered with the Copyright Clearance Center, 222 Rosewood Drive, Danvers, MA 01923, UsA. Organizations in the USA who are also registered with the C.C.C. may, therefore, copy material (beyond the limits permitted by sections 107 and 108 of U.S. Copyright law) subject to payment to the C.C.C of the per copy fee of \$12.oo. This consent does not extend to multiple copying for promotional or commercial purposes. Code 1479-2443/14. ISI Tear Sheet Service, 3501 Market Street, Philadelphia, PA 19104, USA, is authorized to supply single copies of separate articles for private use only. Organizations authorized by the Copyright Licensing Agency may also copy material subject to the usual conditions. For all other use, permission should be sought from Cambridge or from the American branch of Cambridge University Press.

Modern Intellectual History is included in the Cambridge Journals Online service which can be found at http://journals.cambridge.org. For further information on other Press journals access http://cambridge.org/journals.

\section{CAMBRIDGE UNIVERSITY PRESS}

The Edinburgh Building, Shaftesbury Road, Cambridge CB2 8RU, UK

32 Avenue of the Americas, New York, NY 10013-2473 USA

477 Williamstown Road, Port Melbourne, vic 3207, Australia

Ruiz de Alarcón 13, 28014 Madrid, Spain

Dock House, The Waterfront, Cape Town 8001, South Africa

Printed in the UK by Bell \& Bain 


\section{Modern Intellectual History}

Articles

519-548 The Birth of Ukrainian "Active Nationalism": Dmytro Dontsov

and Heterodox Marxism before World War I, 1883-1914

TREVOR ERLACHER

549-574 Why Did Raymond Aron Write that Carl Schmitt Was Not a Nazi? An Alternative

Genealogy of French Liberalism

DANIEL STEINMETZ-JENKINS

575-602 Rewording the Past: The Postwar Publication of a 1938 Lecture by

Martin Heidegger

SIDONIE KELLERER

Forum: Closeness and Distance in the Age of Enlightenment

603-609 Introduction

JOHN BREWER AND SILVIA SEBASTIANI

611-629 History Painting Redistanced: from BenjaminWest to David Wilkie MARK SALBER PHILLIPS

631-653 Discriminating Evidence: Closeness and Distance in Natural and Civil Histories of the Caribbean

MILES OGBORN

655-675 Between Distance and Sympathy: Dr John Moore’s Philosophical Travel Writing JOHN BREWER

677-695 What Constituted Historical Evidence of the New World?

Closeness and Distance in William Robertson and Francisco Javier Clavijero SILVIA SEBASTIANI

697-718 Scales of Time and the Anticipation of the Future: Gibbon, Smith, Playfair JONATHAN SACHS

Review Essays

719-733 In Nostris Extremis (Terror and Fanaticism in the Western Mind) JULIAN BOURG

735-747 A Mainline Moment: The American Protestant Establishment Revisited DAVID SEHAT

749-759 Marcel Mauss and the French "Unconscious" JEFFREY MEHLMAN

761-771 Then as Now, Why Niebuhr?

K. HEALAN GASTON

Cambridge Journals Online

For further information about this journal please go to the journal website at: journals.cambridge.org/mih

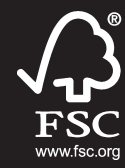

MIX

Paper from responsible sources FSC $^{\circledR}$ C007785
CAMBRIDGE UNIVERSITY PRESS 